\title{
Rapid Regulation of Brain-Derived Neurotrophic Factor mRNA within Eye-Specific Circuits during Ocular Dominance Column Formation
}

\author{
Edward S. Lein and Carla J. Shatz \\ Howard Hughes Medical Institute and Department of Molecular and Cell Biology, University of California, Berkeley, \\ California 94720
}

\begin{abstract}
The neurotrophin brain-derived neurotrophic factor (BDNF) has emerged as a candidate retrograde signaling molecule for geniculocortical axons during the formation of ocular dominance columns. Here we examined whether neuronal activity can regulate BDNF mRNA in eye-specific circuits in the developing cat visual system. Dark-rearing throughout the critical period for ocular dominance column formation decreases levels of BDNF mRNA within primary visual cortex, whereas shortterm (2 d) binocular blockade of retinal activity with tetrodotoxin (TTX) downregulates BDNF mRNA within the lateral geniculate nucleus (LGN) and visual cortical areas. Brief (6 $\mathrm{hr}$ to $2 \mathrm{~d}$ ) monocular TTX blockade during the critical period and also in adulthood causes downregulation in appropriate eye-specific laminae in the LGN and ocular dominance columns within primary visual cortex. Monocular TTX blockade at postnatal day 23 also downregulates BDNF mRNA in a periodic fashion,
\end{abstract}

consistent with recent observations that ocular dominance columns can be detected at these early ages by physiological methods. In contrast, $10 \mathrm{~d}$ monocular TTX during the critical period does not cause a lasting decrease in BDNF mRNA expression in columns pertaining to the treated eye, consistent with the nearly complete shift in physiological response properties of cortical neurons in favor of the unmanipulated eye known to result from long-term monocular deprivation. These observations demonstrate that BDNF mRNA levels can provide an accurate "molecular readout" of the activity levels of cortical neurons and are consistent with a highly local action of BDNF in strengthening and maintaining active synapses during ocular dominance column formation.

Key words: critical period; activity-dependent development; neurotrophins; synaptic competition; neural plasticity; cortical development
In the developing visual cortex of higher mammals, lateral geniculate nucleus (LGN) axons carrying information from the two eyes are initially intermingled within layer 4 and then segregate from one another to form ocular dominance columns (LeVay et al., 1978; Antonini and Stryker, 1993a). This anatomical segregation is accompanied by physiological changes such that the responses of cortical neurons within a column come to be dominated by one eye (Shatz and Stryker, 1978; LeVay et al., 1980). During this period of thalamocortical remodeling, alterations in the levels and patterns of neuronal activity from the two eyes dramatically affect the final pattern of LGN input to visual cortex (Hubel and Wiesel, 1970; Hubel et al., 1977; Daw et al., 1992), indicating that LGN axons from the two eyes compete with one

Received Oct. 4, 1999; revised Nov. 30, 1999; accepted Dec. 2, 1999.

This work was supported by National Institutes of Health Grant EY 02858 and an Alcon Research Institute Award to C.J.S. and a National Science Foundation predoctoral fellowship to E.S.L. C.J.S. is an investigator of the Howard Hughes Medical Institute, and E.S.L. is a Howard Hughes Medical Institute Associate. We thank Holly Aaron and Tilmann Brotz for conceptual and technical assistance with autocorrelation analysis, Andreas Hohn for assistance with cloning of the cat BDNF homolog, and Gene Huh and Roderick Corriveau for use of the cat GAPDH clone and for technical assistance with RNase protection assays. We are grateful to Cynthia Cowdrey for technical assistance with histology and to Denise Escontrias for assistance with animal care.

Correspondence should be addressed to Carla J. Shatz, Howard Hughes Medical Institute, Department of Molecular and Cell Biology, 221 LSA, University of California, Berkeley, Berkeley, CA 94720-3200. E-mail: cshatz@socrates. berkeley.edu.

Dr. Lein's present address: Howard Hughes Medical Institute and Vision Center Laboratory, The Salk Institute, La Jolla, CA 92037.

Copyright (C) 2000 Society for Neuroscience $\quad 0270-6474 / 00 / 201470-14 \$ 15.00 / 0$ another for synaptic territory in an activity-dependent manner (for review, see Shatz, 1990; Katz and Shatz, 1996).

A popular current idea is that this competition involves neurotrophin signaling. The neurotrophins NGF, BDNF, NT-3, and NT-4 are best known for their effects on neuronal survival and differentiation (for review, see Davies, 1994; Conover and Yancopoulos, 1997). Recently they have been implicated in aspects of neuronal plasticity as well (for review, see McAllister et al., 1999; Schuman, 1999), including neurite growth and maintenance (Campenot, 1994; Cohen-Cory and Fraser, 1995; McAllister et al., 1997), synaptic potentiation (Kang et al., 1997), and excitatory and inhibitory synapse formation and quantal amplitude (Rutherford et al., 1998; Vicario-Abejón et al., 1998). Members of the family of neurotrophins have also been implicated in ocular dominance column formation (for review, see Shatz, 1997). Infusion of ligands of the high-affinity trkB receptor, BDNF and NT-4 (Cabelli et al., 1995), or chimeric trkB-IgG recombinant proteins that interfere with normal activation of trkB (Cabelli et al., 1997), into kitten visual cortex prevents the segregation of LGN axons into ocular dominance columns. In related experiments, cortical administration of NT-4 prevents the shrinkage of LGN neurons receiving input from the deprived eye after monocular visual deprivation during the critical period (Riddle et al., 1995).

One of the most compelling features of BDNF as a mediator of synaptic plasticity is that its expression and release are induced by increases in neuronal activity in various experimental paradigms (Gall, 1992; Castren et al., 1993; Goodman et al., 1996; Elmér et al., 1998). Retinal activity blockade, on the other hand, leads to a downregulation of BDNF mRNA levels within rodent visual 
cortex, whereas dark-rearing followed by re-exposure to light leads to a rapid upregulation (Castren et al., 1992; Bozzi et al., 1995; Schoups et al., 1995). Although regulation by neuronal activity does not necessitate involvement in plasticity, signaling molecules involved in activity-dependent synaptic plasticity would be expected to be modulated by neuronal activity in a highly local and rapid manner that would permit them to mediate functional and ultimately enduring structural changes in connectivity. In the present study we have used the cat visual system to analyze local changes in gene expression within well defined eye-specific circuitry in the LGN and visual cortex in response to types of manipulations of retinal activity that are known to lead to changes in the anatomy of the thalamocortical projection and the physiology of cortical neurons.

\section{MATERIALS AND METHODS}

Experiments were performed on 48 cats according to procedures approved by the University of California Berkeley Animal Care and Use Committee and in accordance with Public Health Service policy. Table 1 lists the animals used in this study and the manipulations that were performed.

Dark-rearing. Cats were raised in total darkness from birth until postnatal (P) day 21, 28, or 45. Infrared goggles were used to monitor animals three times daily during this period to ensure normal weight gain and feeding. For RNase protection assays, animals were euthanized in darkness by intraperitoneal injection of sodium pentobarbital $(50 \mathrm{mg} / \mathrm{kg}$; Anthony Products, Arcadia, CA). Brains were removed, and visual areas were dissected, frozen in liquid nitrogen, and stored at $-80^{\circ} \mathrm{C}$ until use. For in situ hybridization, animals were euthanized as described above. Brains were rapidly dissected, flash-frozen in OCT mounting medium (TissueTek; Sakura Finetek, Torrance, CA) in a dry ice-isopentane slurry, and stored at $-80^{\circ} \mathrm{C}$ until further processing.

Tetrodotoxin injections. Tetrodotoxin (TTX), an antagonist of voltagedependent sodium channels that prevents action potentials, was used to block retinal activity completely in kittens and adult cats (Stryker and Harris, 1986). TTX (Calbiochem, La Jolla, CA) was administered by intraocular injection into the posterior chamber of either one or both eyes after induction of anesthesia with isofluorane (3\%) and oxygen (1 $1 / \mathrm{min}$ ). For short-term blockade ( $6 \mathrm{hr}$ to $2 \mathrm{~d}$ ), a single injection of TTX $(1 \mu \mathrm{l} / 100 \mathrm{gm}$ body weight of a $3 \mathrm{~mm}$ solution in $18.6 \mathrm{~mm}$ sodium citrate buffer, $\mathrm{pH} 4.8$ ) was made in the far temporal posterior chamber using a $10 \mu$ l syringe (Hamilton Company, Reno, NV). Control animals received similar injections of $18.6 \mathrm{~mm}$ sodium citrate buffer. For long-term blockade $(10 \mathrm{~d})$, injections were made every $48 \mathrm{hr}$. The pupillary response to illumination was used to monitor the effectiveness of the blockade after administration of TTX (Stryker and Harris, 1986). A single TTX injection was sufficient to produce blockade of the pupillary reflex [and visually evoked cortical responses (Stryker and Harris, 1986)] for at least $48 \mathrm{hr}$. At the end of the blockade period, animals were euthanized, and tissue was collected for RNase protection assays or in situ hybridization as described above.

Transneuronal transport. Transneuronal transport after intraocular injection of ${ }^{3} \mathrm{H}$-proline was used to label ocular dominance columns in layer 4 of visual cortex (LeVay et al., 1978). Injections of ${ }^{3} \mathrm{H}$-proline were performed in addition to TTX eye injections in two animals. P35 animals received a monocular injection of $2 \mathrm{mCi}{ }^{3} \mathrm{H}$-proline $(102 \mathrm{Ci} / \mathrm{mmol}$; Amersham Life Science, Little Chalfont, Buckinghamshire, England) in $50 \mu \mathrm{l} 0.9 \%$ sterile saline into the posterior chamber of the eye as described for TTX injections. After $8 \mathrm{~d}$, animals received a single injection of TTX into the other eye. After an additional $2 \mathrm{~d}$ of monocular activity blockade, animals were deeply anesthetized by an intraperitoneal injection of euthanasia solution, and brains were flash frozen and stored at $-80^{\circ} \mathrm{C}$ until processing.

Cloning of cat BDNF DNA fragments. PCR was used to generate cat BDNF fragments. Sense (GAGAATCGATGACCATCCTTTTCCTT) and antisense (ATATGGATCCCTATCTTCCCCTCTTAAT) BDNF oligonucleotide primers, to which $\mathrm{Cla}$ I and BamHI enzyme restriction sites had been added, corresponded to the first and last six codons, respectively, of unprocessed pig BDNF (Leibrock et al., 1989). PCR using AmpliTaq polymerase (Perkin-Elmer, Norwalk, CT) was performed on 500 ng of cat genomic DNA at low stringency for two cycles ( $1 \mathrm{~min}$ at $96^{\circ} \mathrm{C} ; 2 \mathrm{~min}$ at $45^{\circ} \mathrm{C} ; 1 \mathrm{~min}$ at $72^{\circ} \mathrm{C}$ ), followed by 33 cycles at high stringency $\left(1 \mathrm{~min}\right.$ at $94^{\circ} ; 1 \mathrm{~min}$ at $55^{\circ} \mathrm{C} ; 1 \mathrm{~min}$ at $72^{\circ} \mathrm{C}$, extended for $3 \mathrm{sec}$ per cycle). DNA fragments of the expected size ( 760 base pairs) were cloned into pBluescript $\mathrm{SK}^{+}$(Stratagene, La Jolla, CA). The identity of cat BDNF clones was confirmed by dideoxy nucleotide sequencing and by using the radioactively labeled DNA fragment as a probe in Northern blot analysis on both cat and rat total RNAs. This sequence has been submitted to GenBank (accession number AF192537).

RNase protection assays. Cat BDNF and glyceraldehyde 3-phosphate dehydrogenase (GAPDH) (Corriveau et al., 1998) plasmids were linearized with $A v a \mathrm{II}(\mathrm{BDNF})$ or $N c o$ I (GAPDH) and transcribed with T3 RNA polymerase to yield probes predicted to protect fragments of 362 and 226 bases, respectively. Total RNA samples ( $3 \mu \mathrm{g})$ were adjusted to $5 \mu \mathrm{g}$ with yeast tRNA and analyzed with $\alpha-\left[{ }^{32} \mathrm{P}\right]$-UTP-labeled riboprobes $\left(\sim 1 \times 10^{9} \mathrm{dpm} / \mu \mathrm{g}\right.$ for BDNF; $5 \times 10^{6} \mathrm{dpm} / \mu \mathrm{g}$ for GAPDH $)$ as described (Ausubel, 1992). Briefly, samples were combined with $0.4 \times$ $10^{6} \mathrm{cpm}$ probe, vacuum-dried, resuspended in $25 \mu \mathrm{l}$ hybridization buffer consisting of $80 \%$ deionized formamide, $40 \mathrm{~mm}$ PIPES, pH 6.4, $0.4 \mathrm{~m}$ $\mathrm{NaCl}$, and $1 \mathrm{~mm}$ EDTA, and hybridized at $37^{\circ} \mathrm{C}$ for $10-16 \mathrm{hr}$. Samples were then digested with $20 \mu \mathrm{g} / \mathrm{ml}$ RNase A (Boehringer Mannheim, Indianapolis, IN) in $10 \mathrm{~mm}$ Tris- $\mathrm{HCl}, \mathrm{pH} 8.0,300 \mathrm{~mm} \mathrm{NaCl}$, and $5 \mathrm{~mm}$ EDTA at $15^{\circ} \mathrm{C}$. The RNase was destroyed by adding proteinase $\mathrm{K}$ (Boehringer Mannheim) and SDS to final concentrations of $0.2 \mathrm{mg} / \mathrm{ml}$ and $0.5 \%$, respectively, followed by phenol/chloroform extraction and ethanol precipitation. Samples were resuspended in loading buffer $(95 \%$ formamide, 2 mM EDTA, $\mathrm{pH} 8.0$ ) and run on $6 \%$ denaturing polyacrylamide gels. Quantitation was performed using a phosphorimager (Molecular Dynamics, Sunnyvale, CA). Dark-rearing and binocular activity blockade led to significant (two- to fivefold) changes in BDNF mRNA levels without significant alteration in GAPDH levels. Thus these activity manipulations specifically altered BDNF levels, and quantitative measurements mentioned in the text are given as ratios of BDNF mRNA levels normalized to the GAPDH loading controls.

In situ hybridization. In situ hybridization was performed essentially as described (Simmons et al., 1989; Corriveau et al., 1998; Lein et al., 2000). Cryostat sections $(12 \mu \mathrm{m})$ were cut, air-dried, and stored at $-80^{\circ} \mathrm{C}$ until use. Immediately before use, slides were allowed to thaw at room temperature, fixed for $30 \mathrm{~min}$ in $0.1 \mathrm{M}$ sodium phosphate-buffered $4 \%$ paraformaldehyde, $\mathrm{pH}$ 7.0, and dehydrated through an ethanol series. Sections were then permeabilized with proteinase $\mathrm{K}(1 \mu \mathrm{g} / \mathrm{ml})$, acetylated with acetic anhydride, and dehydrated through an ethanol series. Cat BDNF plasmids were linearized and used for synthesis of sense and antisense $\alpha-\left[{ }^{35} \mathrm{~S}\right]$-labeled riboprobes using T3 or T7 RNA polymerase (Stratagene). Sections were hybridized with these probes for $16-20 \mathrm{hr}$ at $57^{\circ} \mathrm{C}$ with $0.2 \mathrm{ml}$ of $\alpha-\left[{ }^{35} \mathrm{~S}\right]-\mathrm{UTP}$-labeled riboprobe $\left(0.75 \times 10^{7} \mathrm{cpm} / \mathrm{ml}\right)$ in a hybridization solution consisting of $50 \%$ deionized formamide, $10 \%$ dextran sulfate, $0.3 \mathrm{M} \mathrm{NaCl}, 10 \mathrm{~mm}$ Tris- $\mathrm{HCl}, \mathrm{pH}$ 8.0, 1 mм EDTA $\mathrm{pH}$ 8.0, and $1 \times$ Denhardt's solution. After hybridization, coverslips were floated off in $4 \times \mathrm{SSC}$, and sections were incubated in $50 \mu \mathrm{g} / \mathrm{ml}$ RNase A for $30 \mathrm{~min}$ at $37^{\circ} \mathrm{C}$. Sections were then washed through a series of increasingly dilute SSC solutions, beginning at $2 \times \mathrm{SSC}$ at room temperature, and ending with a high stringency wash of $0.1 \times \mathrm{SSC}$ at $60^{\circ} \mathrm{C}$ for 30 min, and finally dehydrated through an ethanol series. For each animal, adjacent sections were hybridized with sense and antisense probes, and control and manipulated sections were processed in parallel to control for variability between experiments. No specific hybridization was seen using sense probes and therefore is not shown.

Autoradiography. After in situ hybridization, sections were dehydrated through a graded ethanol series, defatted in xylene, and dipped for autoradiography in photographic emulsion (NTB-2; Eastman Kodak, Rochester, NY), as described previously (LeVay et al., 1978). Sections were exposed for 3 weeks before development for in situ hybridization, and for 6 weeks to visualize ocular dominance columns after transneuronal transport. For animals receiving ${ }^{3} \mathrm{H}$-proline eye injections, adjacent sections were processed for transneuronal transport only, or for combined transneuronal transport plus in situ hybridization. The 6 week exposure time allows visualization of transneuronally transported ${ }^{3} \mathrm{H}$ proline, whereas the 3 week exposure time allows visualization preferentially of mRNA expression (and low levels of ${ }^{3} \mathrm{H}$-proline, which permits adjacent sections processed in this way to be aligned, as in Fig. 7).

Quantitative analysis. Slides of in situ hybridization for BDNF mRNA were digitized using a cooled CCD camera (SPOT2; Diagnostic Instruments, Sterling Heights, MI) mounted on a Nikon SMZ-U microscope (Nikon, Melville, NY). Grain density in primary visual cortex was quantified by measuring pixel brightness in the digitized images using 
Table 1. Treatments, ages, and observed changes in BDNF mRNA expression in experimental animals

\begin{tabular}{|c|c|c|c|}
\hline $\begin{array}{l}\text { Number } \\
\text { of animals }\end{array}$ & Age and manipulation & $\begin{array}{l}\text { Effect on cortical } \\
\text { BDNF mRNA levels }\end{array}$ & $\begin{array}{l}\text { Effect on LGN BDNF } \\
\text { mRNA levels }\end{array}$ \\
\hline 2 & P21 unmanipulated & n.a. & n.a. \\
\hline 2 & P28 unmanipulated & n.a. & n.a. \\
\hline 4 & P45 unmanipulated & n.a. & n.a. \\
\hline 2 & P90 unmanipulated & n.a. & n.a. \\
\hline 2 & Adult unmanipulated & n.a. & n.a. \\
\hline 7 & P43-P45 binocular TTX & Decreased & Decreased \\
\hline 3 & P43-P45 binocular citrate & No change & No change \\
\hline 1 & $\mathrm{P} 0-\mathrm{P} 21$ dark-reared & Decreased & No change \\
\hline 1 & P0-P28 dark-reared & Decreased & No change \\
\hline 2 & $\mathrm{P} 0-\mathrm{P} 45$ dark-reared & Decreased & No change \\
\hline 3 & P21-P23 monocular TTX & Decreased in patches in V1 & Decreased in eye-specific laminae \\
\hline 2 & P23 6 hr monocular TTX & Decreased in patches in V1 & Decreased in eye-specific laminae \\
\hline 5 & P43-P45 monocular TTX & Decreased in patches in V1 & Decreased in eye-specific laminae \\
\hline 2 & P43-P45 monocular citrate & No change & No change \\
\hline 3 & P45 $6 \mathrm{hr}$ monocular TTX & Decreased in patches in V1 & Decreased in eye-specific laminae \\
\hline 1 & P43-P53 monocular TTX & No change & n.d. \\
\hline 1 & P38-P48 monocular TTX & No change & Decreased in eye-specific laminae \\
\hline & P35-P45 monocular ${ }^{3} \mathrm{H}$-proline + & Decreased in blocked-eye & \\
\hline 2 & P43-P45 monocular TTX & ocular dominance columns & n.d. \\
\hline 1 & P90-P92 monocular TTX & Decreased in patches in V1 & Decreased in eye-specific laminae \\
\hline 2 & Adult $2 \mathrm{~d}$ monocular TTX & Decreased in patches in V1 & Decreased in eye-specific laminae \\
\hline
\end{tabular}

n.a., Not applicable; n.d., not determined.

ImageQuant software (Molecular Dynamics), and the resulting data were processed in two ways. First, peaks in BDNF mRNA signal were defined, and peak-to-peak measurements were made to calculate the period of fluctuations in grain density. Second, the data were processed using an autocorrelation algorithm designed in the IDL programming environment (Research Systems, Boulder, CO). This analysis was performed on the entire cortical thickness (e.g., all of the layers combined) and on layers $2 / 3,4$, or $5 / 6$ separately. Included are cases of monocular TTX injections at P23 and P45 and in adult ( $n=2$ animals in each case) and normal P45 animals $(n=2)$.

\section{RESULTS}

Results are presented in three sections. The first section examines the regulation of BDNF mRNA in visual structures after binoc- ular activity blockade or rearing in the dark. The second section examines the regulation of BDNF mRNA within eye-specific circuits in the LGN and visual cortex after brief (6 hr to $2 \mathrm{~d}$ ) monocular blockade of retinal activity. Ocular dominance columns form in the cat visual cortex between P21 and P50, as assessed by transneuronal labeling (LeVay et al., 1978) and reconstructions of individual LGN axonal arbors (Antonini and Stryker, 1993a). Experimental manipulations described in the first two sections were performed near the end of thalamocortical segregation (around P45) to examine the regulation of BDNF mRNA within eye-specific cortical circuits once ocular dominance columns are well on their way to forming. The critical

Figure 1. RNase protection assessment of dark-rearing or brief binocular TTX injections on BDNF mRNA levels in visual structures of the cat during the critical period. Animals used for RNase protection assays were either raised in the dark from birth to P45 (P45 Dark-Reared; $n=1)$, received binocular TTX injections at P43 and were assayed at P45 (P45 Bin.TTX; $n=2$ ), received binocular injections of sodium citrate vehicle solution at P43 and were assayed at P45 (P45 Bin.Cit.; $n=1$ ), or were unmanipulated (P45 Normal; $n=2$ ). Total RNA was extracted from primary visual cortex, frontal cortex, LGN, and superior colliculus and analyzed by RNase protection assays with a cat-specific ${ }^{32} \mathrm{P}$-labeled BDNF riboprobe (top band). A cat-specific GAPDH riboprobe (bottom band) was used in the same hybridization mixture as an internal control for RNA quantifica-

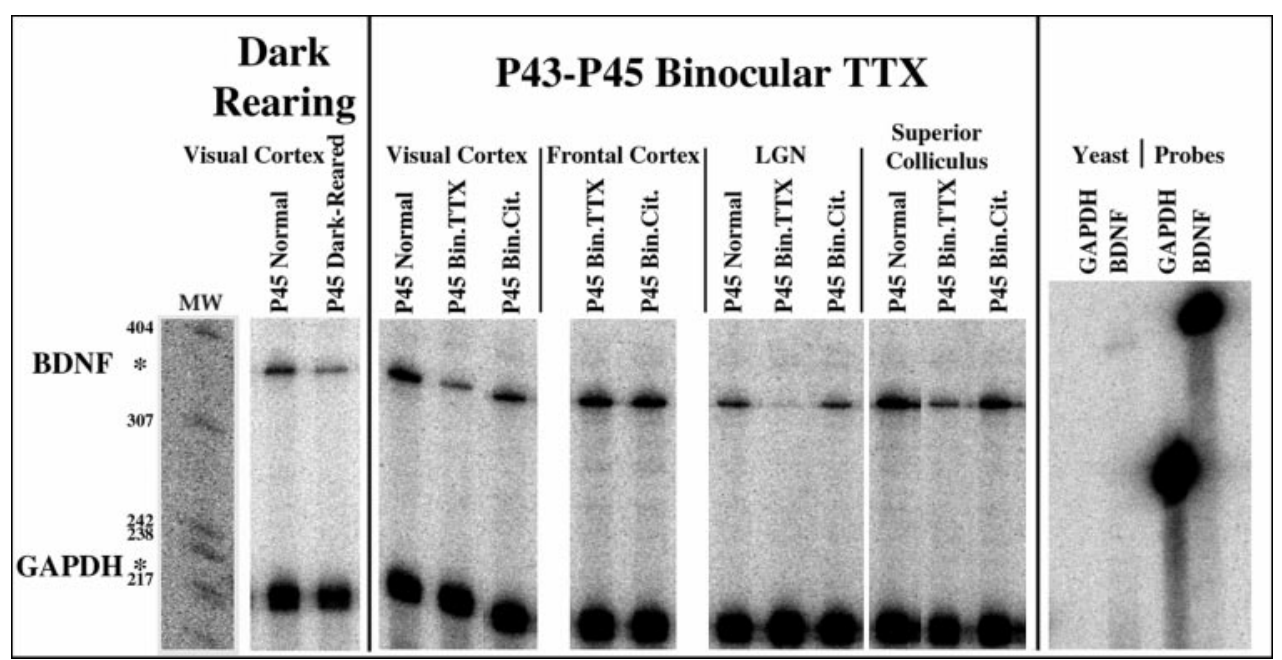

tion. Protected fragments for BDNF and GAPDH (362 and 226 nucleotides, respectively) are indicated by asterisks. Each lane was loaded with total RNA from a single animal. The right-most four lanes contain control hybridizations using yeast tRNA and undigested probes for GAPDH and BDNF. $M W$, Molecular weight markers. 


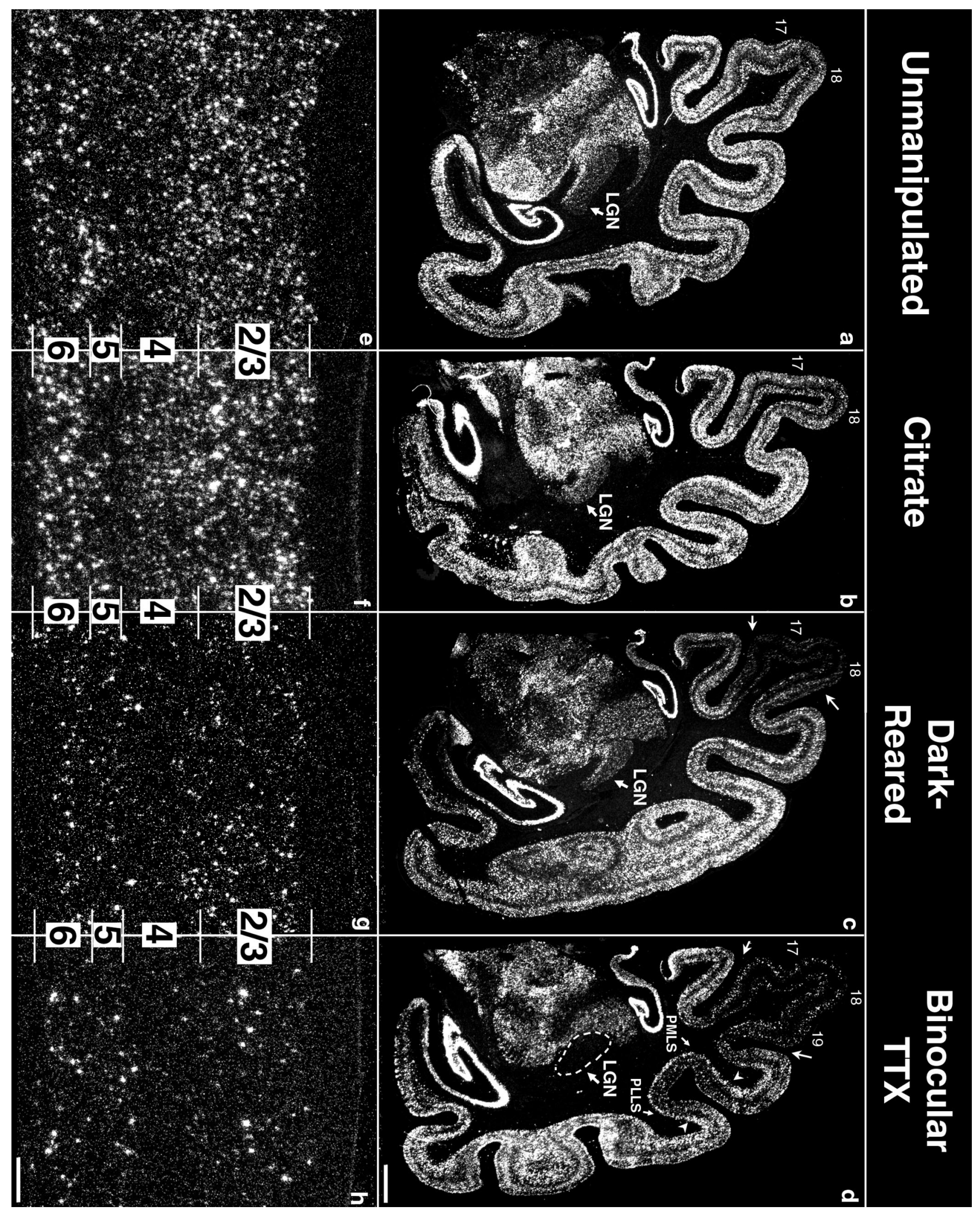

Figure 2. Dark-rearing or brief binocular TTX treatments reduce BDNF mRNA levels in visual structures. $a-d$, Dark-field photomicrographs of $i n$ situ hybridization for BDNF mRNA on coronal sections from an unmanipulated P45 animal $(a)$, after binocular injections of sodium citrate vehicle on P43 and examination at P45 $(b)$, dark-rearing from birth to P45 $(c)$, or binocular injections of TTX at P43 and examination at P45 $(d)$. The reduction of BDNF mRNA expression is limited to visual cortical areas 17 and 18 (c, arrows) after dark-rearing and is quite marked in (Figure legend continues) 
Figure 3. Effects of dark-rearing or brief binocular activity blockade on BDNF mRNA levels in the lateral geniculate nucleus. Cresyl violetcounterstained coronal sections from an unmanipulated P45 animal $(a)$, an animal that received binocular sodium citrate injections on P43 and was examined at P45 (c), an animal that received binocular TTX injections on P43 and was examined at $\mathrm{P} 45(e)$, or an animal that was dark-reared from birth to P45 (g). $b, d, f, h$, Dark-field photomicrographs of in situ hybridization for BDNF mRNA on sections adjacent to those in $a, c, e, g$. A clear reduction in BDNF mRNA expression is detectable after TTX treatment $(f)$ but not after dark-rearing $(h)$. Medial is to the left and dorsal is up. $A, A 1$, and $C$ denote LGN laminae. Scale bar, $500 \mu \mathrm{m}$.

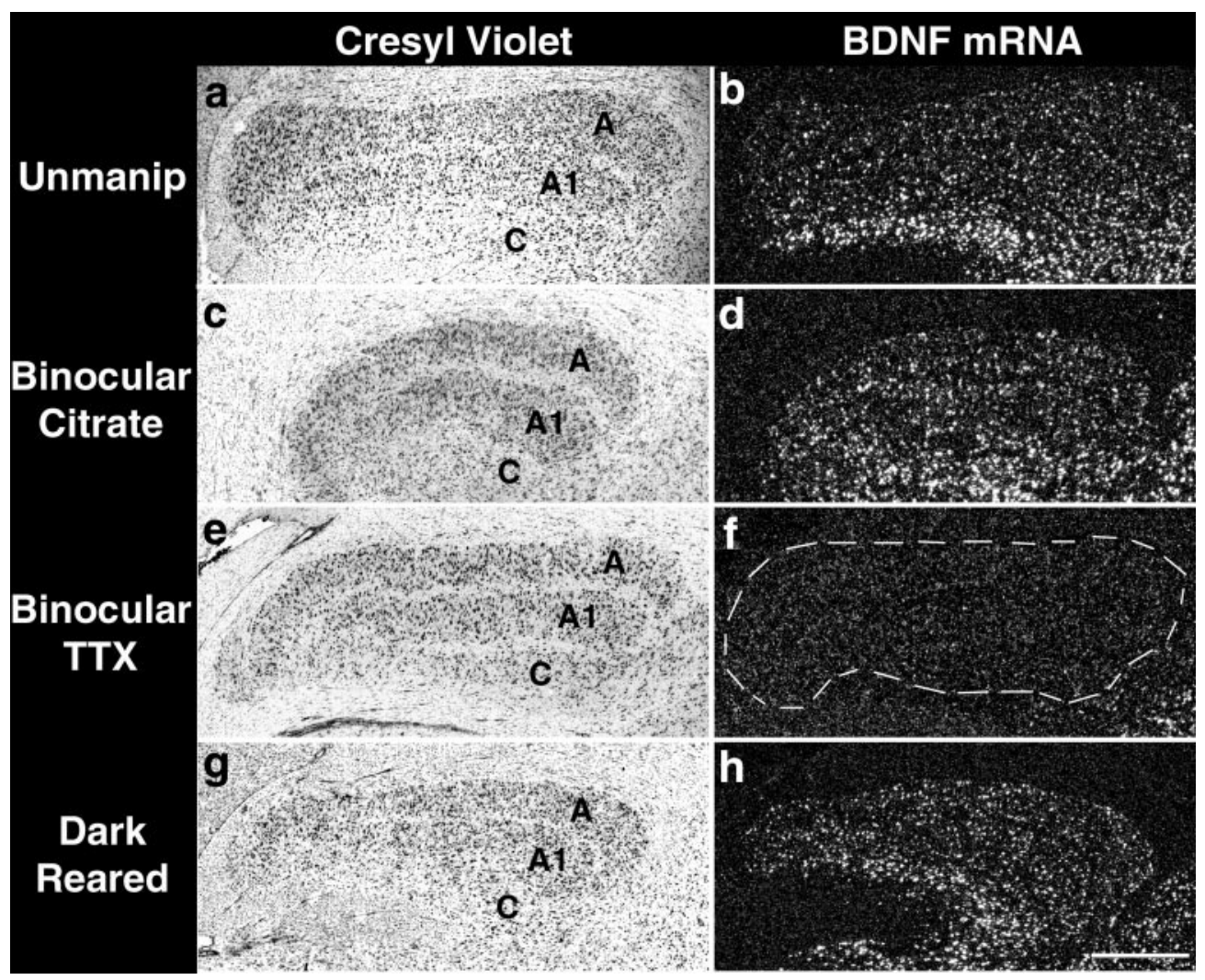

period during which manipulations of retinal activity can alter thalamocortical branching patterns is correlated with the period of thalamocortical segregation (Shatz and Stryker, 1978; Antonini and Stryker, 1993b); it is worth noting that other cortical layers have longer critical periods (Mower et al., 1985; Daw et al., 1992) and that synaptic plasticity in layers $2 / 3$ is present even in adulthood (Hirsch and Gilbert, 1993; Darian-Smith and Gilbert, 1994). Hence, the final section describes the regulation of BDNF mRNA within visual cortex both before and after the classically defined critical period for the segregation of thalamocortical axons within layer 4 and into adulthood. Results obtained from all experimental manipulations are summarized in Table 1.

\section{Dark-rearing or brief binocular blockade of retinal activity during ocular dominance column formation selectively decreases BDNF mRNA levels in visual structures}

As shown in the RNase protection assays in Figure 1, BDNF mRNA is expressed in the primary visual cortex, frontal cortex, lateral geniculate nucleus (LGN) and superior colliculus at P45, near the end of the critical period for segregation of LGN axons within layer 4. Rearing animals in the dark from birth to P45 decreases neural activity within visual pathways by blocking visually driven retinal activity [but not spontaneous retinal activity (Mastronarde, 1983)]. This treatment diminishes the upregulation of BDNF mRNA within primary visual cortex that normally occurs during this period (Lein et al., 2000). Quantification of RNase protections indicates that BDNF mRNA levels are roughly twofold lower than in normal animals at P45 when animals are dark-reared from birth. After complete blockade of retinal activity for $2 \mathrm{~d}$ via binocular TTX injections from P43 to $\mathrm{P} 45, \mathrm{BDNF}$ mRNA levels are also reduced by approximately twofold relative to normal animals or animals receiving vehicle injections. This downregulation is specific to visual cortex and is not observed in frontal cortex. Complete blockade of retinal activity also leads to a downregulation of BDNF mRNA in subcortical structures receiving direct retinal input: the LGN (approximately fivefold reduction) and superior colliculus (approximately twofold reduction). Thus, BDNF mRNA levels can be modulated in visual structures by global alterations in retinal activity within both eyes, in agreement with previous studies in rodents (Castren et al., 1992; Bozzi et al., 1995; Schoups et al., 1995).

To assess the specific neuronal populations in which BDNF mRNA levels are affected, cellular expression patterns after activity manipulations were examined using in situ hybridization. BDNF mRNA is expressed throughout the neocortex at P45, as well as in the LGN (Fig. 2a). In unmanipulated animals, levels of BDNF mRNA are normally slightly lower in visual areas 17 and 18 than surrounding cortical regions (Fig. $2 a$ ). Dark-rearing from birth until P45 decreases BDNF mRNA levels relative to normal,

both areas 17 and 18 and in a number of other visual cortical areas $(19, P M L S, P L L S)$ after TTX treatment $(d$, arrows and arrowheads). $e-h$ show magnifications of primary visual cortex. In comparison to unmanipulated $(e)$ or vehicle-injected animals $(f)$, fewer heavily labeled cells are present after dark-rearing $(g)$ or binocular TTX treatment $(h)$. Dorsal is up and medial to the left in these sections. Numbers in $d-f$ denote cortical layers. 17 , Area 17, primary visual cortex; 18, 19, visual cortical areas 18 and 19; PMLS, posteromedial lateral suprasylvian sulcus; PLLS, posterolateral lateral suprasylvian sulcus; $L G N$, lateral geniculate nucleus. Cortical regions were assigned based on cytoarchitectural landmarks (Tusa et al., 1978, 1979; Rosenquist, 1985) and examination of Nissl-stained sections adjacent to those processed for in situ hybridization. Scale bars: $a-d, 2 \mathrm{~mm} ; e-h, 200 \mu \mathrm{m}$. 
specifically in visual areas 17 and 18 (Fig. 2c). Two day TX blockade from P43 to P45 also decreases BDNF mRNA levels, but the effect is more pronounced and widespread than that of dark-rearing: decreased expression levels are found not only in visual cortical areas 17 and 18 but also in several other secondary visual cortical areas (Fig. $2 d$, area 19, PMLS, PLLS). The pattern of BDNF mRNA expression after binocular injection of citrate vehicle at P43 and analysis at P45 is identical to that of unmanipulated animals (Fig. 2b). Closer examination of the laminar patterns of expression within primary visual cortex reveals that these activity manipulations lead to a decrease in the number of cells expressing detectable levels of BDNF mRNA in all cortical layers. Previous studies have indicated that BDNF mRNA is expressed in neurons of the cerebral cortex and not in glial cells (Castren et al., 1992; Huntley et al., 1992). In normal or vehicleinjected animals (Fig. $2 e, f$ ), strong hybridization is present on large (presumably pyramidal) neurons in deep $(5,6)$ and superficial (2/3) cortical layers, with lower levels on small (presumably stellate) neurons in layer 4. Dark-rearing (Fig. $2 g$ ) or binocular TTX application (Fig. $2 h$ ) leads to a decrease in the number of cells expressing BDNF mRNA. This effect is pronounced after binocular TTX injections and is particularly apparent within layer 4. A number of large cells in deep and superficial cortical layers maintain high levels of expression, indicating that not all cortical neurons require afferent activity to maintain BDNF mRNA expression.

BDNF mRNA levels in the LGN are also dramatically affected by binocular retinal activity blockade (Figs. $2 d, 3 f$ ). BDNF mRNA is detectable via in situ hybridization in the LGN at P45 in normal and citrate vehicle-injected animals (Figs. $2 a, b, 3 b, d$ ). Two day binocular activity blockade decreases levels of BDNF mRNA throughout the LGN below the limits of detectability with this technique (Figs. 2d, 3f). Dark-rearing, on the other hand, does not lead to a detectable change in expression levels in the LGN with respect to normal or vehicle-injected animals (Figs. $2 c$, $3 h)$. It is notable that spontaneous retinal activity is known to persist in dark-reared animals (Mastronarde, 1983). The dramatic decrease in cellular BDNF mRNA expression after TTX injections is consistent with the RNase protection assays described above and suggests that spontaneously generated retinal activity is sufficient to maintain BDNF mRNA expression levels in the majority of LGN neurons but not in those of primary visual cortex.

The superficial layers of the superior colliculus also receive direct projections from the retina (Daw, 1995). At P45, many heavily labeled cells are present in the retinorecipient layers of the superior colliculus (Fig. 4a). Binocular blockade of retinal activity for $2 \mathrm{~d}$ greatly reduces the number of strongly hybridized cells within these layers (Fig. 4b) but not in deeper layers, which receive polymodal sensory input (Daw, 1995). Thus, taken together, these results indicate that retinal activity is necessary to maintain BDNF mRNA expression, within both subcortical and cortical visual areas that receive their primary excitatory drive from the retina.

\section{Monocular activity blockade reveals eye-specific patterns of BDNF mRNA expression within visual pathways}

To examine whether BDNF mRNA can be regulated within local circuitry in the LGN and visual cortex, short-term monocular blockades of retinal activity were performed during the critical period, and the resulting cellular expression patterns were ana-
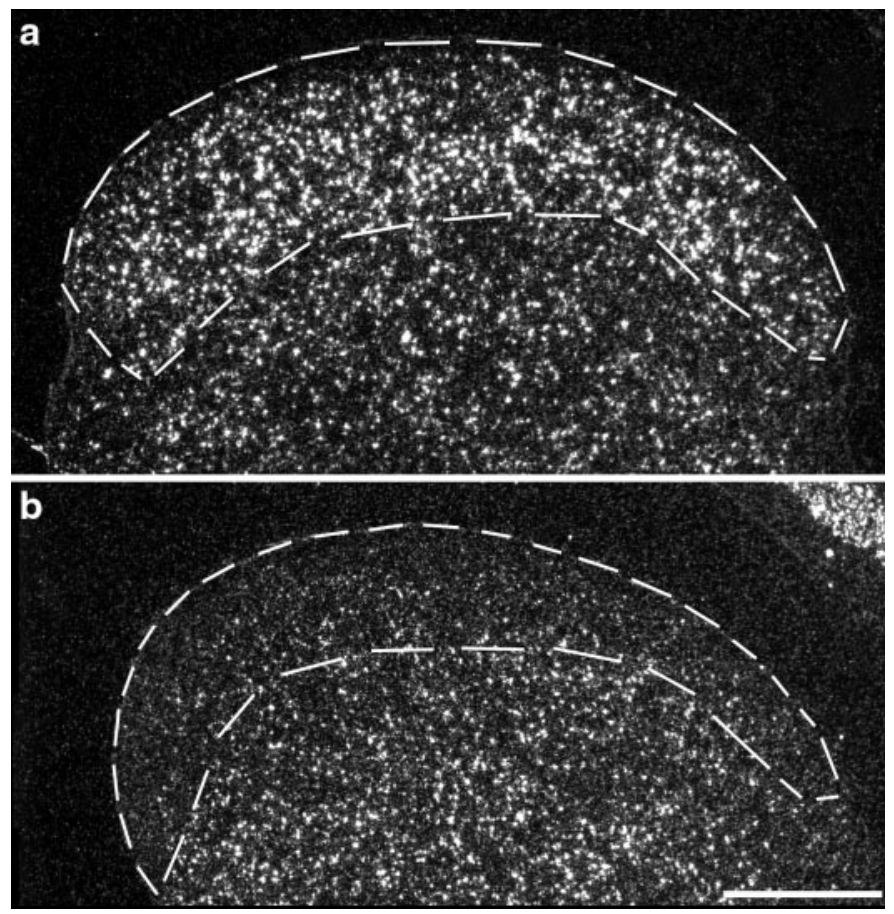

Figure 4. Effects of brief binocular activity blockade on BDNF mRNA levels in the superior colliculus. Shown are dark-field photomicrographs of in situ hybridization for BDNF mRNA on coronal sections through the superior colliculus after binocular injections of citrate vehicle $(a)$ or tetrodotoxin $(b)$ at $\mathrm{P} 43$ and examination at $\mathrm{P} 45$. Reduction in cellular hybridization after TTX treatment is present only in superficial layers (outlined). Medial is to the left and dorsal is up. Scale bar, $500 \mu \mathrm{m}$.

lyzed using in situ hybridization. The LGN is a laminated structure in which each layer receives input only from one eye (Hickey and Guillery, 1974). Each retina projects contralaterally to lamina A and ipsilaterally to lamina A1. A 2 d monocular blockade of retinal activity with TTX from P43 to P45 selectively decreases BDNF mRNA expression specifically in the layers innervated by the silenced retina. Virtually no labeled cells are present in lamina A1 in the hemisphere ipsilateral to the injected eye (Fig. $5 c$ ), whereas virtually no label is present in layer $\mathrm{A}$ of the contralateral hemisphere (Fig. $5 d$ ). In contrast, many labeled cells are present in layers corresponding to the active eye (Fig. $5 c, d$ ). There is no obvious change in BDNF mRNA in either layer after monocular injections of citrate vehicle (data not shown). These observations demonstrate that retinal activity regulates BDNF mRNA levels specifically within appropriate eye-specific layers within the LGN.

To determine whether the circuit specificity of BDNF mRNA regulation is present at the next stage of visual processing, expression patterns in primary visual cortex were examined after short-term monocular activity blockade. BDNF mRNA levels were monitored by in situ hybridization at P45, near the end of the critical period. We chose this specific age because it is when LGN axons subserving the two eyes are almost completely segregated from one another into ocular dominance columns within layer 4 of primary visual cortex (LeVay et al., 1978), but when brief periods of monocular deprivation can still produce significant changes in their arborization (Antonini and Stryker, 1993b). Thus, blockade of activity in one eye should modulate BDNF expression in a patchy columnar pattern if the expression of 
Figure 5. Brief monocular activity blockade decreases BDNF mRNA expression in eye-specific laminae of the lateral geniculate nucleus. Cresyl violet counterstained horizontal sections $(a$, $b$ ) or dark-field photomicrographs of in situ hybridization for BDNF mRNA on adjacent sections $(c, d)$ from the ipsilateral and contralateral hemispheres after monocular injection of tetrodotoxin on P43 and examination at P45. The levels of BDNF mRNA are decreased only in the laminae receiving input from the TTX-treated eye. (Medial is to the right in $a$ and $c$ and to the left in $b$ and $d$. Anterior is to the top.) $A$ and $A 1$ denote laminae in the LGN. Scale bar, $500 \mu \mathrm{m}$.

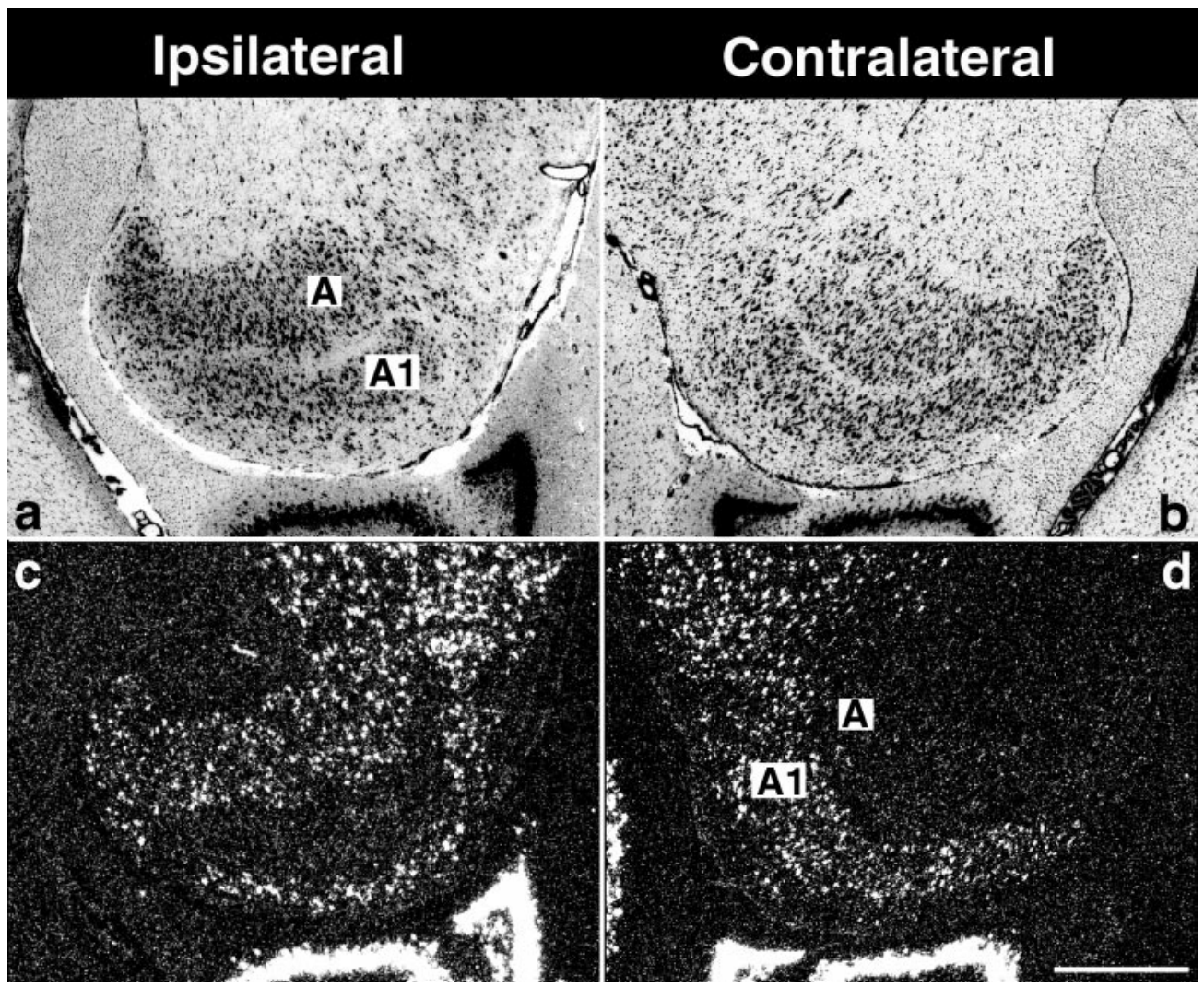

BDNF mRNA is controlled within eye-specific circuitry in visual cortex. In control animals, BDNF mRNA is expressed evenly across the tangential extent of primary visual cortex (Fig. 6a). However, after monocular blockade of retinal activity with TTX from $\mathrm{P} 43$ to $\mathrm{P} 45$, the pattern of BDNF mRNA expression consists of a regular series of alternating patches of high and low expression across primary visual cortex (Fig. $6 b, c$ ); outside visual cortex, expression is even. Patches of cells expressing high levels of BDNF mRNA extend through all cortical layers (Fig. $6 c$ ), but in general they are most apparent in layers 4 and $2 / 3$. This patchy expression pattern is more pronounced in the hemisphere contralateral to the blocked eye than in the ipsilateral hemisphere (data not shown). A possible explanation for this observation is that monocular blockade removes a greater amount of functional input to the contralateral visual cortex, because it is known that there is a strong physiological bias in favor of contralateral input particularly at early ages in visual cortical development (Hubel and Wiesel, 1965; Crair et al., 1998). All of the subsequent analyses describe BDNF mRNA expression in the hemisphere contralateral to the blocked eye.

Periodic fluctuations in levels of BDNF mRNA expression after monocular activity blockade were quantified by locating peaks in the hybridization signal and measuring the distance between peaks (see Materials and Methods). The average periodicity was $0.95 \mathrm{~mm}$, consistent with that of cat ocular dominance columns as measured using transneuronal transport $(\sim 1 \mathrm{~mm}$ wide $=$ width of right + left eye column) (Shatz et al., 1977; LeVay et al., 1978; Anderson et al., 1988). As an objective measure of peak assessment, we also performed autocorrelation analyses across visual cortex to detect regular patterns of fluctuations in grain density (see Fig. 10). This analysis, discussed further below, also revealed a regular fluctuation in BDNF
mRNA levels with a peak-to-peak period of $\sim 1 \mathrm{~mm}$. These regular fluctuations were most evident in layers 4 and $2 / 3$ and lend further support to the idea that BDNF mRNA levels are regulated within ocular dominance columns.

To show definitively that the patches of high BDNF mRNA levels indeed coincide with ocular dominance columns receiving input from the active eye, we combined the techniques of transneuronal transport to label LGN terminal arbors in layer 4 with in situ hybridization for BDNF mRNA after monocular TTX blockade from $\mathrm{P} 43$ to $\mathrm{P} 45$. As shown in Figure 7, patches of cells expressing high levels of BDNF mRNA correspond precisely to ocular dominance columns representing the active $\left({ }^{3} \mathrm{H}\right.$-prolineinjected) eye. Thus, blockade of retinal activity in one eye leads to a selective downregulation of BDNF mRNA within ocular dominance columns corresponding to that eye. BDNF mRNA is regulated in a columnar pattern in primary visual cortex (and in the LGN; data not shown) after monocular activity blockades as brief as $6 \mathrm{hr}$ (Fig. 8a), the shortest period of blockade tested.

Long-term monocular deprivation causes dramatic anatomical and physiological changes in cortical ocular dominance, such that LGN axons subserving the nondeprived eye come to occupy the majority of layer 4 of primary visual cortex (Hubel et al., 1977; Shatz and Stryker, 1978), and most cortical neurons respond physiologically only to the nondeprived eye (Hubel and Wiesel, 1970). Consistent with the known physiological takeover of cortex by the active eye, after $10 \mathrm{~d}$ of monocular TTX blockade during the critical period, BDNF mRNA levels are uniformly high across the tangential extent of cortex and columns are no longer evident (Fig. 8b). Thus, both in the LGN and primary visual cortex, neuronal activity in each eye regulates the expression of BDNF in neural circuitry whose responses are dominated by that eye. 

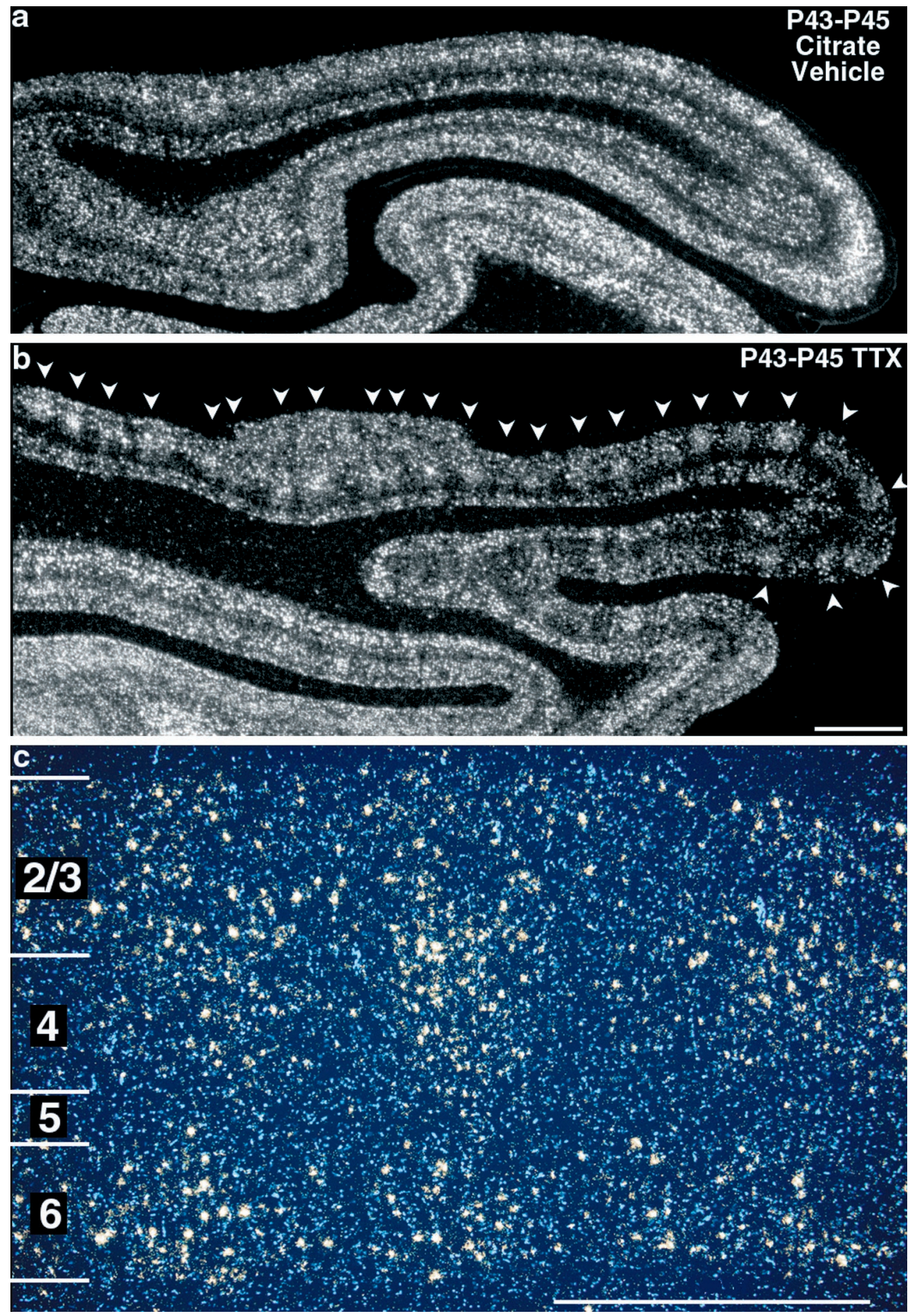

Figure 6. Monocular activity blockade decreases BDNF mRNA levels in periodic patches across primary visual cortex. Shown are dark-field photomicrographs of in situ hybridization for BDNF mRNA on horizontal sections through primary visual cortex after either a monocular citrate vehicle injection $(a)$ or an injection of TTX $(b)$ on $\mathrm{P} 43$ and examination at P45. TTX treatment leads to a patchy expression pattern in visual cortex ( $b$, arrowheads). Higher magnification of visual cortex in a section hybridized for BDNF mRNA (white silver grains) and counterstained with the fluorescent dye bisbenzimide (blue) to show cortical layers (c) demonstrates that the patchy expression extends through all cortical layers. Posterior is to the right and medial is $u p$. Numbers denote cortical layers. Scale bar: $a, b, 2 \mathrm{~mm} ; c, 1 \mathrm{~mm}$. In this and all subsequent figures, BDNF mRNA hybridization is shown on cortical sections contralateral to the eye receiving TTX injections.

\section{BDNF mRNA levels are modulated by afferent activity before and after the peak of the critical period}

It is well known that there is an extended period of activitydependent plasticity, particularly in layers $2 / 3$, that persists into adulthood (Mower et al., 1985; Daw et al., 1992; Hirsch and Gilbert, 1993; Darian-Smith and Gilbert, 1994). Thus, we examined whether BDNF mRNA can still be regulated beyond the period of LGN axon segregation into ocular dominance columns in layer 4. BDNF mRNA expression in visual cortex was examined after short-term monocular activity blockades at times outside of the period for anatomical segregation of LGN axons in layer 4 (LeVay et al., 1978). BDNF mRNA levels can be modulated by retinal activity even at 3 months of age and beyond: $2 \mathrm{~d}$ after monocular TTX injections at P90 or in adult cats, BDNF mRNA expression in primary visual cortex consists of a regular series of patches of high alternating with low expression (Fig. $9 a, b)$, with a periodicity consistent with that of mature ocular dominance columns (Shatz et al., 1977; Anderson et al., 1988) (Fig. 10). BDNF mRNA levels in the LGN are also decreased within layers receiving input from the TTX-treated eye at these ages (data not shown). Thus, BDNF mRNA levels can be modulated by retinal activity within eye-specific cortical and subcor- 


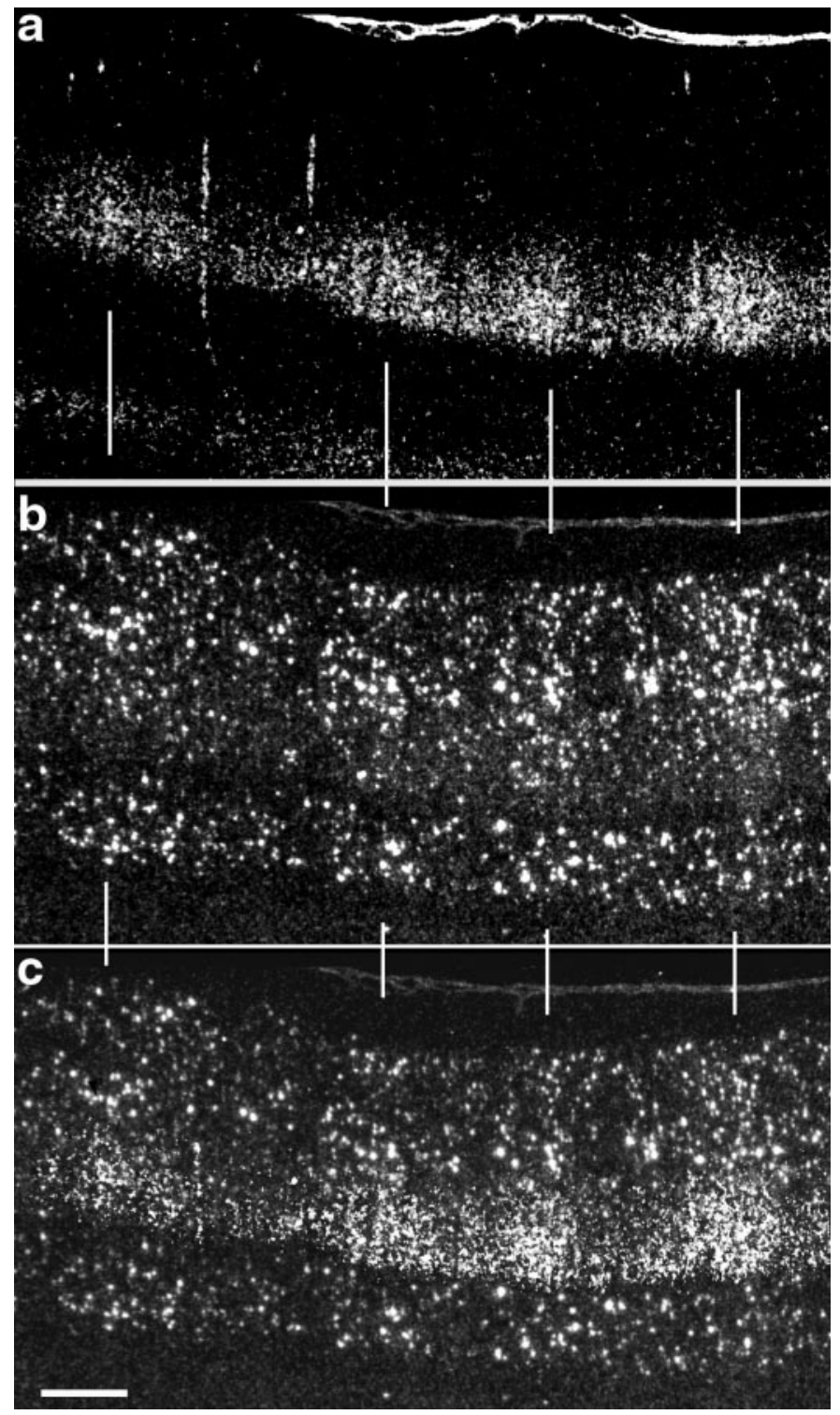

Figure 7. Patches of BDNF mRNA expression in visual cortex after monocular TTX application correspond to anatomically defined ocular dominance columns. Shown are dark-field photomicrographs of horizontal sections through the visual cortex after monocular injection of ${ }^{3} \mathrm{H}$ proline in one eye on P35, injection of TTX into the other eye on P43, and examination at $\mathrm{P} 45$. Sections are taken from the hemisphere ipsilateral to the ${ }^{3} \mathrm{H}$-proline-injected eye and contralateral to the TTX-injected eye. $a$, Dark-field photomicrograph of ${ }^{3} \mathrm{H}$-proline labeling: silver grains are clustered into ocular dominance patches in layer 4 representing the injected eye. $b$, Dark-field photomicrograph of in situ hybridization for BDNF mRNA on an adjacent section. $c$, Overlay of ${ }^{3} \mathrm{H}$-proline autoradiograph onto in situ hybridization demonstrates that ocular dominance columns in layer 4 coincide with patches of high levels of BDNF mRNA expression. Scale bar, $500 \mu \mathrm{m}$.

tical circuits past the period of thalamocortical axonal plasticity and into adulthood.

Recently Stryker and colleagues (Crair et al., 1998) have demonstrated, using optical imaging, that physiologically defined ocular dominance columns can be detected in cat primary visual cortex as early as P14, even before it is possible to detect the segregation of LGN axons into patches within layer 4 of primary visual cortex using anatomical methods (LeVay et al., 1978; Antonini and Stryker, 1993a). In view of our observations above that BDNF mRNA levels appear to follow levels of ocular activity faithfully at older ages, we asked whether ocular dominance columns for BDNF mRNA could be revealed after short-term monocular activity blockade at these very early ages, before clear anatomical segregation of LGN terminal arbors. Indeed, $6 \mathrm{hr}$ after monocular TTX injection on P23, a downregulation of BDNF mRNA is evident in superficial layers of primary visual cortex (Fig. 9c) in the hemisphere contralateral to the injected eye, consistent with the previously reported strong contralateral physiological bias at this age (Crair et al., 1998). This downregulation in visual cortex [and in the LGN (data not shown)] is also present after $2 \mathrm{~d}$ of monocular TTX blockade starting at P21. An overall decrease in levels of BDNF mRNA is particularly prominent in posterior visual cortex. Most notable are clusters of heavily labeled cells present slightly more anteriorly in visual cortex that have a periodicity of $\sim 1 \mathrm{~mm}$ (Fig. 10), similar to that of ocular dominance columns at older ages. Taken together with the findings of Crair et al. (1998), these observations imply that BDNF mRNA expression patterns can mirror eye-specific physiological responses of visual cortical neurons even before the anatomically defined segregation of LGN axons into ocular dominance columns in layer 4.

To examine whether similar periodic fluctuations in BDNF mRNA levels are present after monocular activity blockade at different ages, and to determine the layers in which periodicity is present at these ages, we performed peak-to-peak measurements and autocorrelation analyses of BDNF mRNA grain density across primary visual cortex of animals receiving brief monocular blockades at P23 $(n=2)$ and P45 $(n=2)$, or in adulthood $(n=$ $2)$, as well as in unmanipulated animals at P45 $(n=2)$. Two day monocular TTX blockade in adults leads to a periodic pattern of BDNF mRNA expression that can be detected in all cortical layers (Fig. 10a), with an average period of $0.93 \pm 0.30 \mathrm{~mm}$. At P45, 6 hr blockade causes a similar periodic downregulation (average $0.95 \pm 0.32 \mathrm{~mm}$ ) that is most prominent in layers 4 and 2/3 (Fig. 10b). TTX blockade (6 h) at P23 also leads to periodic fluctuations in BDNF mRNA with a periodicity consistent with blockade at older ages (average $0.95 \pm 0.33 \mathrm{~mm}$ ), but this periodicity is only detectable in layers $2 / 3$ (Fig. 10c) [BDNF mRNA is normally barely detectable in layer 4 at this age (Lein et al., 2000)]. In contrast, the autocorrelation analysis of BDNF mRNA grain density in unmanipulated (Fig. 10d) animals is quite different from that in TTX-injected animals, because there are no detectable fluctuations in grain density except in layers $2 / 3$. The presence of periodic fluctuations in layers $2 / 3$ in control animals perhaps suggests a physiological clustering of active inputs normally in these layers, consistent with the clustering of inputs to the centers of ocular dominance columns observed in the silver stain studies of LeVay et al. (1975). Thus, the autocorrelation analysis confirms quantitatively the fundamental observations of this study that BDNF mRNA levels can be modulated locally in cortex by monocular activity blockade; furthermore, this analysis shows that there is a developmental shift in the laminar locale of this regulation.

\section{DISCUSSION}

The present study demonstrates that BDNF mRNA levels can provide an accurate molecular readout of neural activity within visual structures. Brief blockade of retinal activity during the critical period for ocular dominance column formation decreases BDNF mRNA levels within eye-specific circuitry in both the LGN and visual cortex. This local and rapid regulation could 

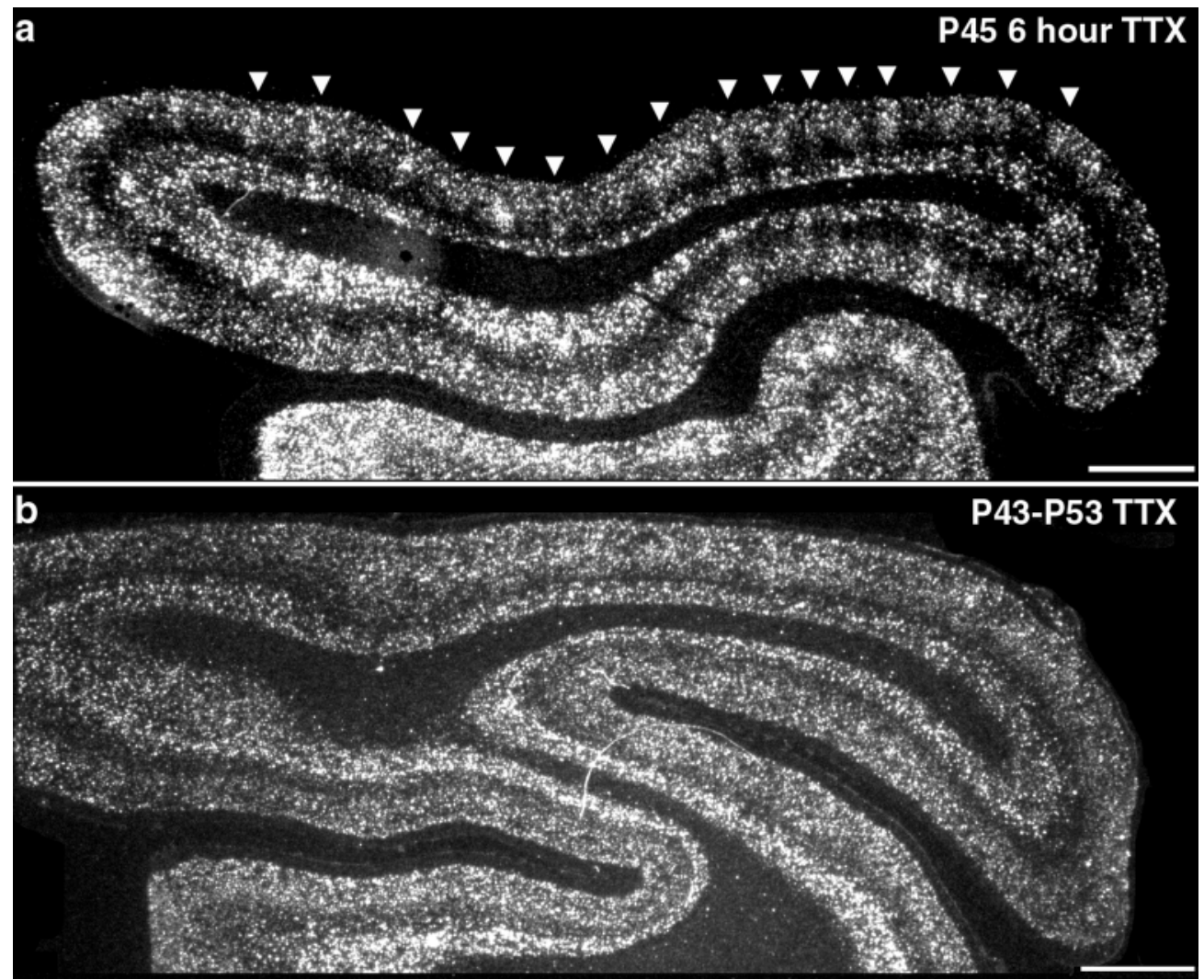

Figure 8. Effects of short- versus longterm monocular activity blockade on BDNF mRNA expression in visual cortex during the critical period. Shown are dark-field photomicrographs of in situ hybridization for BDNF mRNA on horizontal sections through primary visual cortex. $a$, BDNF mRNA expression $6 \mathrm{hr}$ after monocular injection of TTX at P45. $b$, BDNF mRNA expression after $10 \mathrm{~d}$ of monocular TTX injections from P43 to P53. Columnar expression pattern is present after shortterm ( $a$, arrowheads) but not long-term monocular blockades. Posterior is to the right and medial is up. Scale bar, $2 \mathrm{~mm}$.

permit BDNF to play a role in effecting changes in anatomy and physiology known to result from alteration of visual experience during the critical period, as well as in adult synaptic plasticity in visual cortex.

\section{BDNF mRNA levels are differentially regulated by dark- rearing and complete blockade of retinal activity}

Altering the total amount of retinal activity during early postnatal development in cats and monkeys affects the eventual anatomical and physiological architecture of connectivity within primary visual cortex (for review, see Shatz, 1990; Katz and Shatz, 1996). Complete blockade of retinal action potentials by binocular TTX application prevents segregation of thalamocortical axons into ocular dominance columns within layer 4 and maintains the immature binocular response properties of layer 4 neurons (Stryker and Harris, 1986). In contrast, in some studies ocular dominance columns do eventually form in animals reared in darkness (Mower et al., 1985), although not in others (Swindale, 1988). Dark-rearing also extends the "critical" period during which manipulations of visual experience can alter the eye preference of cortical neurons as assessed physiologically (Cynader et al., 1980; Mower et al., 1985). Previous studies in rodents had demonstrated a decrease in BDNF mRNA levels in visual cortex after dark-rearing, eyelid suture, or pharmacological blockade of retinal activity (Castren et al., 1992; Bozzi et al., 1995; Schoups et al., 1995). Dark-rearing retards the normal developmental increase of BDNF mRNA levels in visual cortex, which are rapidly restored to normal levels after re-exposure to light (Castren et al., 1992; Schoups et al., 1995). Consistent with these results, we find that both dark-rearing and binocular TTX application lead to the downregulation of BDNF mRNA levels within visual structures, but with significant differences. Two day binocular TTX application near the end of the critical period (P45) downregulates
BDNF expression in the LGN and primary visual cortex (area 17) and secondary visual cortical areas [areas 18 and 19, posteromedial lateral suprasylvian sulcus (PMLS), posterolateral lateral suprasylvian sulcus (PLLS)]. Dark-rearing from birth to P45, on the other hand, leads to a decrease in BDNF mRNA levels only in areas 17 and 18 and no detectable decreases in the LGN or other secondary visual areas. This difference between the two manipulations suggests that spontaneous retinal activity [which is known to persist in dark-reared animals (Mastronarde, 1983)] is sufficient to maintain BDNF expression, at least in some visual structures.

\section{In situ hybridization for BDNF mRNA reveals eye- specific circuitry after monocular activity blockade}

A major finding of this study is that short-term blockade of retinal activity in one eye leads to a downregulation of BDNF mRNA locally within eye-specific circuitry in the LGN and visual cortex. Previous work in rodents had shown that monocular deprivation for several weeks in rats leads to a downregulation of BDNF mRNA in visual cortical areas that is more pronounced in the monocular subfield than the binocular subfield (Bozzi et al., 1995). In cat visual cortex this downregulation is seen in ocular dominance columns corresponding to the blocked eye, as demonstrated directly by aligning the pattern of transneuronally transported radioactive label in LGN axon terminals with zones of BDNF mRNA hybridization. Monocular activity blockade can reveal ocular dominance columns, as assessed by in situ hybridization for BDNF mRNA, as rapidly as $6 \mathrm{hr}$ after TTX injection. Furthermore, this regulation within local circuitry is seen not only during the critical period, but also into adulthood, as discussed further below.

Ocular dominance columns are thought to form between P21 


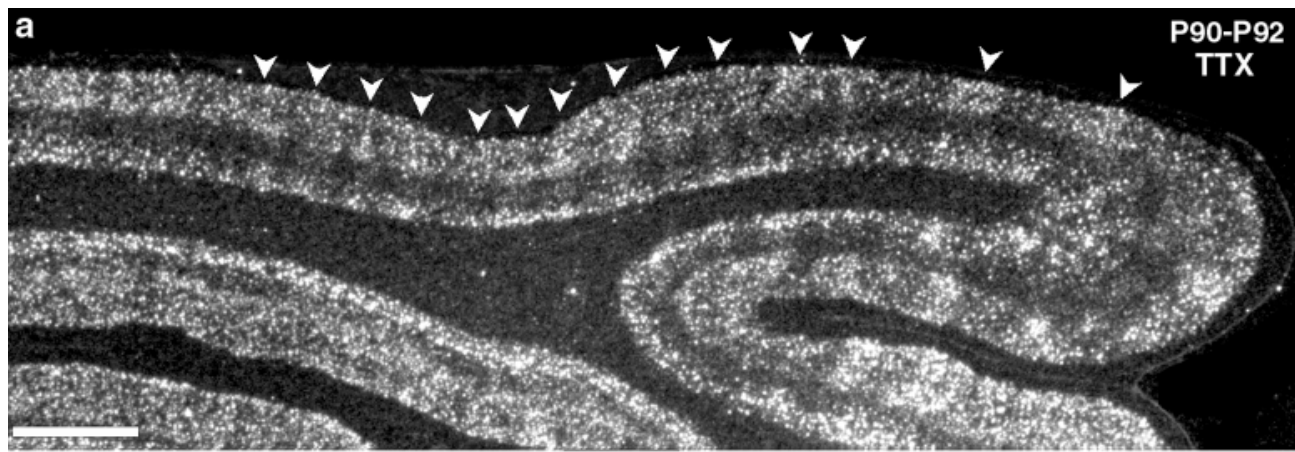

Figure 9. Monocular activity blockade alters BDNF expression in adulthood and even before LGN axon segregation. Shown are dark-field photomicrographs of in situ hybridization for BDNF mRNA on horizontal sections through primary visual cortex after monocular injections of TTX at P90 $(a)$, in an adult $(b)$, or at P23 (c). Monocular activity blockade for $2 \mathrm{~d}$ reveals a patchy columnar pattern of BDNF mRNA expression at $\mathrm{P} 90$ and in the adult $(a, b$, arrowheads). Blockade for $6 \mathrm{hr}$ at P23 (c) reveals patchy expression of BDNF in superficial cortical layers in anterior visual cortex ( $c$, arrowheads) and a large downregulation throughout the superficial cortical layers in posterior visual cortex. Posterior is to the right and medial is up. Scale bars, $2 \mathrm{~mm}$.

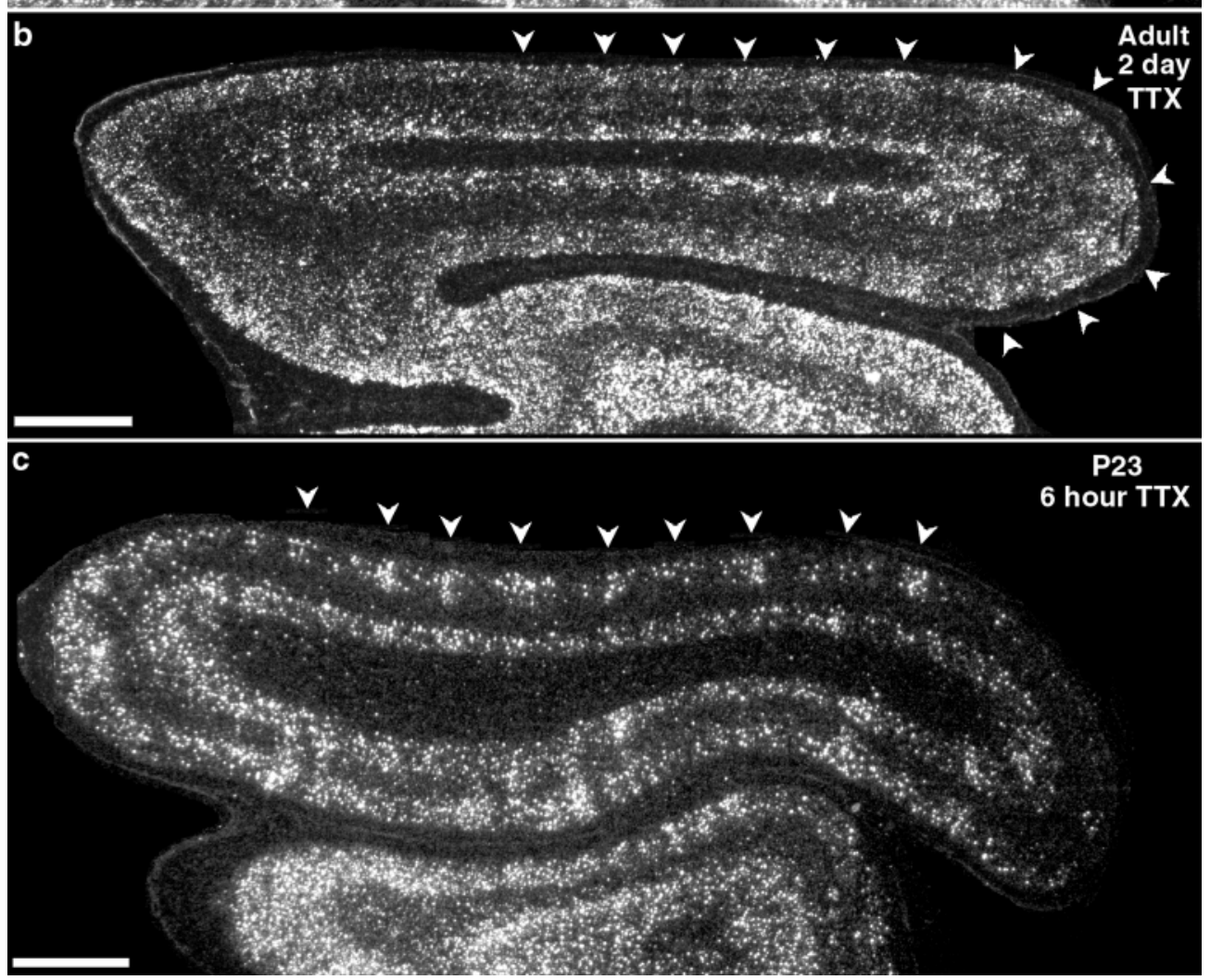

and P50 based on studies using transneuronal autoradiography (LeVay et al., 1978). We observed a patchy, periodic fluctuation in BDNF mRNA after monocular activity blockade at surprisingly early times in postnatal cortical development (P23), before a clear anatomical segregation of LGN axons into ocular dominance columns in layer 4. Recently, using optical imaging techniques, Stryker and colleagues (Crair et al., 1998) found that physiological responses to each eye are segregated spatially into ocular dominance regions, functionally marking the beginning of columns even at P14. They also reported finding a strong contralateral eye bias [as has been noted previously in the cat (Hubel and Wiesel, 1965)]. Consistent with these findings, we observe here that monocular TTX at P23 produces a fluctuating pattern of BDNF mRNA expression in primary visual cortex with a period of $\sim 1 \mathrm{~mm}$, the width of a right + left eye column (Shatz et al., 1977; Anderson et al., 1988), and that the effect on BDNF mRNA expression is more profound contralateral to the blocked eye. Taken together, these findings imply that the functional segregation of LGN axons into ocular dominance columns precedes the global anatomical rearrangements of LGN terminal arbors. This conclusion of "function before structure" has also been made in studies of the development of the patchy horizontal connections within layers 2/3 of visual cortex (for review, see Nelson and Katz, 1995; Katz and Shatz, 1996).

A final correlation linking BDNF mRNA expression patterns to underlying patterns of neural activity comes from our finding that prolonged $(10 \mathrm{~d})$ monocular TTX blockades during the critical period do not produce obvious fluctuations in BDNF mRNA expression within visual cortex. It is well known that long-term monocular deprivation leads to dramatic anatomical (Hubel et al., 1977) and physiological (Hubel et al., 1977; Shatz and Stryker, 1978) changes in favor of the nondeprived eye, such that the vast majority of cortical neurons come to be responsive only to the active eye. The fact that cortical BDNF mRNA expression is uniform after long-term (but not short-term) monocular deprivation is consistent with the idea that the active eye now controls the activity, and hence BDNF mRNA expression, in the majority of cortical neurons. Taken together, these observations demonstrate that BDNF mRNA levels can mirror the physiological responses of visual cortical neurons. 


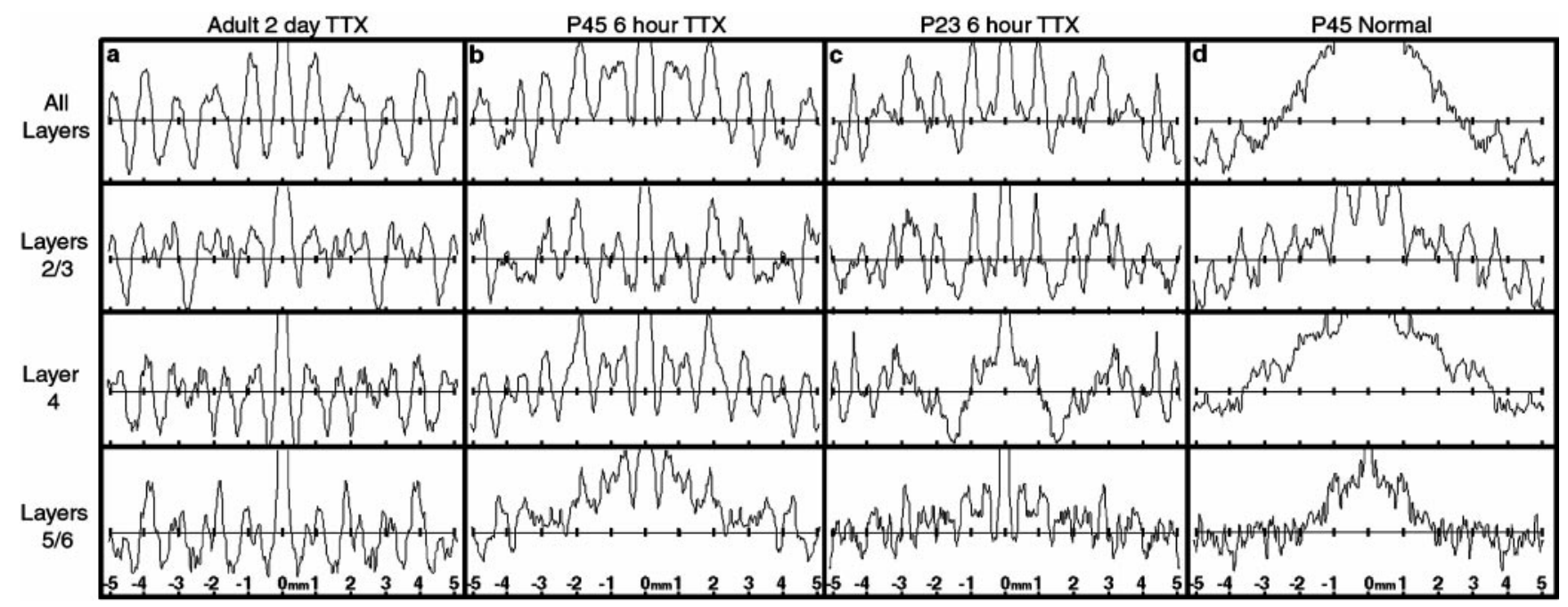

Figure 10. Autocorrelation analysis demonstrates periodic fluctuations in BDNF mRNA signal after monocular activity blockade at different ages. Shown is autocorrelation analysis of BDNF mRNA grain density in different cortical layers of primary visual cortex after monocular TTX blockade for $2 \mathrm{~d}$ in an adult $(a), 6 \mathrm{hr}$ at $\mathrm{P} 45(b)$, or $6 \mathrm{hr}$ at P23 $(c)$, or in a normal animal at P45 $(d)$. Regular fluctuations in grain density with a period of $\sim 1 \mathrm{~mm}$ can be detected in all cortical layers after TTX blockade in the adult, but are most apparent in layers $2 / 3$ at younger ages and also in layer 4 at P45. No periodic fluctuation is present in layers 4 or $5 / 6$ in normal animals, although some periodicity is evident in superficial layers $2 / 3$.

\section{Implications of rapid regulation of BDNF for mechanisms of neurotrophin action during ocular dominance column formation and plasticity}

An important implication of our observations on the activitydependent regulation of BDNF mRNA is that the changes in BDNF precede and are involved in synaptic plasticity both during the critical period and thereafter. Here, we use the term "plasticity" to refer not only to the functional and structural reorganization of connections that occurs during the critical period and that can be altered by monocular deprivation, but also to the physiologically assessed synaptic plasticity demonstrated by the persistence of long-term potentiation (LTP) and long-term depression (LTD) in layers 2/3 of the adult visual cortex (Kirkwood et al., 1993; Darian-Smith and Gilbert, 1994). We do not favor the alternative interpretation, that BDNF is simply regulated by activity but not involved in synaptic plasticity, for reasons discussed below.

First, BDNF is thought to play a major role in ocular dominance column formation and plasticity. Infusion of either BDNF (Cabelli et al., 1995) or agents that prevent the activation of its high-affinity tyrosine kinase receptor trkB (Cabelli et al., 1997) into kitten visual cortex during the critical period prevents the segregation of LGN axons, suggesting a role in the regulation and maintenance of LGN axonal branching. One current hypothesis is that LGN axons compete with one another for neurotrophin produced by layer 4 neurons in an activity-dependent manner (Thoenen, 1995; Bonhoeffer, 1996; Shatz, 1997; McAllister et al., 1999). In support of such a direct effect of BDNF on thalamocortical axons, LGN neurons are known to express trkB during the critical period (Allendoerfer et al., 1994; Cabelli et al., 1996), and BDNF mRNA is present, albeit at low levels, in layer 4 neurons (Fig. 2e) (Lein et al., 2000), Our observations that monocular TTX application leads to a downregulation of BDNF mRNA within layer 4 neurons receiving input from the blocked eye is consistent with such an action on LGN axons. A growing literature also implicates BDNF in modulation of synaptic transmission and physiological synaptic plasticity (for review, see
McAllister et al., 1999; Schuman, 1999). In visual cortex, infusions of BDNF coupled with monocular deprivation lead to a paradoxical ocular dominance shift in favor of the deprived eye (Galuske et al., 1996), demonstrating BDNF effects on physiologically assessed ocular dominance as well.

Next, manipulations similar to those performed in this study are known to lead to changes in anatomical and physiological ocular dominance. The effects of activity blockade on the structure of LGN axon terminal arbors have been observed as early as 4-6 d after monocular deprivation (Antonini and Stryker, 1993b, 1996). Effects of monocular deprivation during the critical period on the physiological ocular dominance of cortical neurons can occur even more rapidly, on the order of $6 \mathrm{hr}$ to $2 \mathrm{~d}$ (Olson and Freeman, 1978; Mioche and Singer, 1989). [Yet more rapid changes in ocular dominance have been reported by Frégnac et al. (1988) when stimulation of one eye is paired with depolarization of the recorded neuron]. Because BDNF regulation within ocular dominance columns can be detected within $6 \mathrm{hr}$ of activity blockade (the shortest time examined here) as early as P23, BDNF regulation occurs early enough in development to precede, and could be rapid enough to drive, the known structural and physiological changes that result from monocular deprivation.

The ongoing regulation of BDNF mRNA by visual activity beyond the critical period, particularly in structures like the LGN, would seem to be an example of activity-dependent regulation independent of synaptic plasticity. However, recent studies indicate that cellular mechanisms of synaptic plasticity, such as LTP, persist in adult visual cortex, particularly in layers 2/3 (Hirsch and Gilbert, 1993; Kirkwood et al., 1993), where we have observed a striking columnar modulation of BDNF mRNA expression after brief monocular TTX blockade at both P90 and in the adult. Moreover, in vivo experiments have also demonstrated an anatomical reorganization of connections within layers $2 / 3$ in adult visual cortex after peripheral denervation (Darian-Smith and Gilbert, 1994). The continued modulation of BDNF by activity observed here may point to an additional role for this neurotrophin in mechanisms of cortical plasticity in the adult. 


\section{REFERENCES}

Allendoerfer KL, Cabelli RJ, Escandon E, Kaplan DR, Nikolics K, Shatz CJ (1994) Regulation of neurotrophin receptors during the maturation of the mammalian visual system. J Neurosci 14:1795-1811.

Anderson PA, Olavarria J, Van Sluyters RC (1988) The overall pattern of ocular dominance bands in cat visual cortex. J Neurosci 8:2183-2200.

Antonini A, Stryker MP (1993a) Development of individual geniculocortical arbors in cat striate cortex and effects of binocular impulse blockade. J Neurosci 13:3549-3573.

Antonini A, Stryker MP (1993b) Rapid remodeling of axonal arbors in the visual cortex. Science 260:1819-1821.

Antonini A, Stryker MP (1996) Plasticity of geniculocortical afferents following brief or prolonged monocular occlusion in the cat. J Comp Neurol 369:64-82.

Ausubel FM (1992) Short protocols in molecular biology. New York: Wiley.

Bonhoeffer T (1996) Neurotrophins and activity-dependent development of the neocortex. Curr Opin Neurobiol 6:119-126.

Bozzi Y, Pizzorusso T, Cremisi F, Rossi FM, Barsacchi G, Maffei L (1995) Monocular deprivation decreases the expression of messenger RNA for brain-derived neurotrophic factor in the rat visual cortex. Neuroscience 69:1133-1144.

Cabelli RJ, Hohn A, Shatz CJ (1995) Inhibition of ocular dominance column formation by infusion of NT-4/5 or BDNF. Science 267:1662-1666.

Cabelli RJ, Allendoerfer KL, Radeke MJ, Welcher AA, Feinstein SC, Shatz CJ (1996) Changing patterns of expression and subcellular localization of TrkB in the developing visual system. J Neurosci 16:7965-7980.

Cabelli RJ, Shelton DL, Segal RA, Shatz CJ (1997) Blockade of endogenous ligands of trkB inhibits formation of ocular dominance columns. Neuron 19:63-76

Campenot RB (1994) NGF and the local control of nerve terminal growth. J Neurobiol 25:599-611.

Castren E, Zafra F, Thoenen H, Lindholm D (1992) Light regulates expression of brain-derived neurotrophic factor mRNA in rat visual cortex. Proc Natl Acad Sci USA 89:9444-9448.

Castren E, Pitkanen M, Sirvio J, Parsadanian A, Lindholm D, Thoenen H, Riekkinen PJ (1993) The induction of LTP increases BDNF and NGF mRNA but decreases NT-3 mRNA in the dentate gyrus. NeuroReport 4:895-898.

Cohen-Cory S, Fraser SE (1995) Effects of brain-derived neurotrophic factor on optic axon branching and remodelling in vivo. Nature 378:192-196.

Conover JC, Yancopoulos GD (1997) Neurotrophin regulation of the developing nervous system: analyses of knockout mice. Rev Neurosci 8:13-27.

Corriveau RA, Huh GS, Shatz CJ (1998) Regulation of class I MHC gene expression in the developing and mature CNS by neural activity. Neuron 21:505-520.

Crair MC, Gillespie DC, Stryker MP (1998) The role of visual experience in the development of columns in cat visual cortex. Science 279:566-570.

Cynader M, Timney BN, Mitchell DE (1980) Period of susceptibility of kitten visual cortex to the effects of monocular deprivation extends beyond six months of age. Brain Res 191:545-550.

Darian-Smith C, Gilbert CD (1994) Axonal sprouting accompanies functional reorganization in adult cat striate cortex. Nature 368:737-740.

Davies AM (1994) The role of neurotrophins in the developing nervous system. J Neurobiol 25:1334-1348.

Daw NW (1995) Visual development. New York: Plenum.

Daw NW, Fox K, Sato H, Czepita D (1992) Critical period for monocular deprivation in the cat visual cortex. J Neurophysiol 67:197-202.

Elmér E, Kokaia Z, Kokaia M, Carnahan J, Nawa H, Lindvall O (1998) Dynamic changes of brain-derived neurotrophic factor protein levels in the rat forebrain after single and recurring kindling-induced seizures. Neuroscience 83:351-362.

Frégnac Y, Shulz D, Thorpe S, Bienenstock E (1988) A cellular analogue of visual cortical plasticity. Nature 333:367-370.

Gall CM (1992) Regulation of brain neurotrophin expression by physiological activity. Trends Pharmacol Sci 13:401-403.
Galuske RAW, Kim DS, Castren E, Thoenen H, Singer W (1996) Brainderived neurotrophic factor reverses experience-dependent synaptic modifications in kitten visual cortex. Eur J Neurosci 8:1554-1559.

Goodman LJ, Valverde J, Lim F, Geschwind MD, Federoff HJ, Geller AI, Hefti F (1996) Regulated release and polarized localization of brain-derived neurotrophic factor in hippocampal neurons. Mol Cell Neurosci 7:222-238.

Hickey TL, Guillery RW (1974) An autoradiographic study of retinogeniculate pathways in the cat and the fox. J Comp Neurol 156:239-254.

Hirsch JA, Gilbert CD (1993) Long-term changes in synaptic strength along specific intrinsic pathways in the cat visual cortex. J Physiol (Lond) 461:247-262.

Hubel DH, Wiesel TN (1965) Binocular interaction in striate cortex of kittens reared with artificial squint. J Neurophysiol 28:1041-1059.

Hubel DH, Wiesel TN (1970) The period of susceptibility to the physiological effects of unilateral eye closure in kittens. J Physiol (Lond) 206:419-436.

Hubel DH, Wiesel TN, LeVay S (1977) Plasticity of ocular dominance columns in monkey striate cortex. Philos Trans R Soc Lond B Biol Sci 278:377-409.

Huntley GW, Benson DL, Jones EG, Isackson PJ (1992) Developmental expression of brain derived neurotrophic factor mRNA by neurons of fetal and adult monkey prefrontal cortex. Dev Brain Res 70:53-63.

Kang H, Welcher AA, Shelton D, Schuman EM (1997) Neurotrophins and time: different roles for TrkB signaling in hippocampal long-term potentiation. Neuron 19:653-664.

Katz LC, Shatz CJ (1996) Synaptic activity and the construction of cortical circuits. Science 274:1133-1138.

Kirkwood A, Dudek SM, Gold JT, Aizenman CD, Bear MF (1993) Common forms of synaptic plasticity in the hippocampus and neocortex in vitro. Science 260:1518-1521.

Leibrock J, Lottspeich F, Hohn A, Hofer M, Hengerer B, Masiakowski P, Thoenen H, Barde YA (1989) Molecular cloning and expression of brain-derived neurotrophic factor. Nature 341:149-152.

Lein ES, Hohn A, Shatz CJ (2000) Dynamic regulation of BDNF and NT-3 expression during visual system development. J Comp Neurol, in press.

LeVay S, Hubel DH, Wiesel TN (1975) The pattern of ocular dominance columns in macaque visual cortex revealed by a reduced silver stain. J Comp Neurol 159:559-576.

LeVay S, Stryker MP, Shatz CJ (1978) Ocular dominance columns and their development in layer IV of the cat's visual cortex: a quantitative study. J Comp Neurol 179:223-244.

LeVay S, Wiesel TN, Hubel DH (1980) The development of ocular dominance columns in normal and visually deprived monkeys. J Comp Neurol 191:1-51.

Mastronarde DN (1983) Correlated firing of cat retinal ganglion cells. I. Spontaneously active inputs to $\mathrm{X}$ and $\mathrm{Y}$ cells. J Neurophysiol 49:303-324.

McAllister AK, Katz LC, Lo DC (1997) Opposing roles for endogenous BDNF and NT-3 in regulating cortical dendritic growth. Neuron 18:767-778.

McAllister AK, Katz LC, Lo DC (1999) Neurotrophins and synaptic plasticity. Annu Rev Neurosci 22:295-318.

Mioche L, Singer W (1989) Chronic recordings from single sites of kitten striate cortex during experience-dependent modifications of receptivefield properties. J Neurophysiol 62:185-197.

Mower GD, Caplan CJ, Christen WG, Duffy FH (1985) Dark rearing prolongs physiological but not anatomical plasticity of the cat visual cortex. J Comp Neurol 235:448-466.

Nelson DA, Katz LC (1995) Emergence of functional circuits in ferret visual cortex visualized by optical imaging. Neuron 15:23-34.

Olson CR, Freeman RD (1978) Monocular deprivation and recovery during sensitive period in kittens. J Neurophysiol 41:65-74.

Riddle DR, Lo DC, Katz LC (1995) NT-4-mediated rescue of lateral geniculate neurons from effects of monocular deprivation. Nature 378:189-191.

Rosenquist AC (1985) Connections of visual cortical areas in the cat. In: Cerebral cortex, Vol 3, Visual cortex (Peters A, Jones EG, eds), pp 81-117. New York: Plenum.

Rutherford LC, Nelson SB, Turrigiano GG (1998) BDNF has opposite effects on the quantal amplitude of pyramidal neuron and interneuron excitatory synapses. Neuron 21:521-530. 
Schoups AA, Elliott RC, Friedman WJ, Black IB (1995) NGF and BDNF are differentially modulated by visual experience in the developing geniculocortical pathway. Dev Brain Res 86:326-334.

Schuman EM (1999) Neurotrophin regulation of synaptic transmission. Curr Opin Neurobiol 9:105-109.

Shatz CJ (1990) Impulse activity and the patterning of connections during CNS development. Neuron 5:745-756.

Shatz CJ (1997) Neurotrophins and visual system plasticity. In: Molecular and cellular approaches to neural development (Cowan WM, Jessell TM, Zipursky SL, eds), pp 509-524. Oxford: Oxford UP.

Shatz CJ, Stryker MP (1978) Ocular dominance in layer IV of the cat's visual cortex and the effects of monocular deprivation. J Physiol (Lond) 281:267-283.

Shatz CJ, Lindstrom S, Wiesel TN (1977) The distribution of afferents representing the right and left eyes in the cat's visual cortex. Brain Res 131:103-116.

Simmons DM, Arriza JL, Swanson LW (1989) A complete protocol for in situ hybridization of messenger RNAs in brain and other tissues with radiolabeled single-stranded RNA probes. J Histotech 12:169-181.

Stryker MP, Harris WA (1986) Binocular impulse blockade prevents the formation of ocular dominance columns in cat visual cortex. J Neurosci 6:2117-2133.

Swindale NV (1988) Role of visual experience in promoting segregation of eye dominance patches in the visual cortex of the cat. J Comp Neurol 267:472-488.

Thoenen H (1995) Neurotrophins and neuronal plasticity. Science 270:593-598.

Tusa RJ, Palmer LA, Rosenquist AC (1978) The retinotopic organization of area 17 (striate cortex) in the cat. J Comp Neurol 177:213-235.

Tusa RJ, Rosenquist AC, Palmer LA (1979) Retinotopic organization of areas 18 and 19 in the cat. J Comp Neurol 185:657-678.

Vicario-Abejón C, Collin C, McKay RD, Segal M (1998) Neurotrophins induce formation of functional excitatory and inhibitory synapses between cultured hippocampal neurons. J Neurosci 18:7256-7271. 